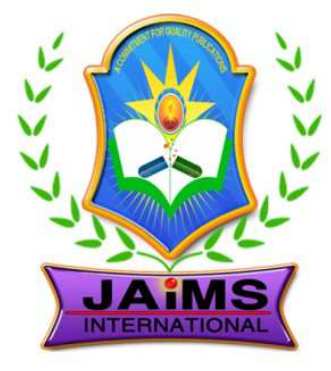

ISSN 2456-3110 Vol 1 - Issue 1 May-Jun 2016

Journal of

Ayurveda and Integrated Medical Sciences

www.jaims.in

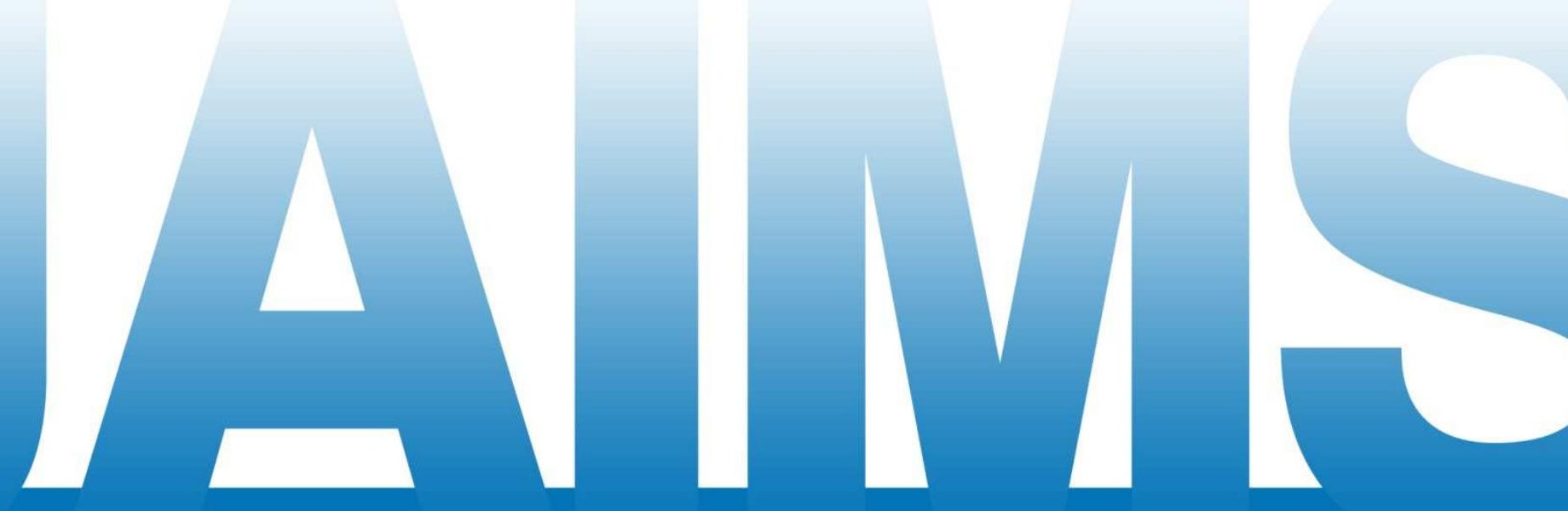




\title{
To Evaluate the efficacy of Aahara -Vihara on Stanya Kshaya in Healthy Female Volunteers of different Deha Prakriti
}

\author{
Kiran Tanwar, Uma Shankar Sharma, ${ }^{1}$ Ankur Kumar Tanwar. ${ }^{2}$ \\ Post Graduate Scholar, ${ }^{1}$ Professor and Head of Sharira Kriya, Ayurvedic and Unani Tibbia College, New Delhi, India. \\ ${ }^{2}$ Project Associate, Ch. Brahm Prakash Ayurved Charak Sansthan, Khera Dabar, New Delhi, India.
}

\section{A B S TR A C T}

\begin{abstract}
Ayurveda is a practical science that deals with physiological and pathological status of human beings. Acharyas of Ayurveda has classified the elements of the body under three fundamental components Dosa, Dhatu and Mala. Though the basic elements are categorised under these three groups but some elements are left which are not defined. These specialised group of elements termed as Updhatu. Upa is suggestive of 'Proximity' and close resemblance to the term Dhatu. So in nutshell, it could be said that Updhatu is derivative of Dhatu and has some resemblance in terms of structure, function, and nature. The present study evaluate the role of the efficacy of Aahara-Vihara on Stanyaksaya in healthy female volunteers of different Deha Prakriti.The study was undertaken on 30 Females having Stanyaksaya and baby in Ksirapa Avastha in a single group. The duration of therapy was 3 months. The patients were followed up every 2 weeks. This trial revealed that this disease is common in VataKapha Prakriti patients. After treatment, statistically significant $(\mathrm{p}<0.01)$ reduction was observed in selected parameters. We found that the Aahara-Vihara was found effective in Stanyaksaya. On the basis of above observation, it may be recommended that this diet (Ahara-Vihara) is a safe and effective in the management of Stanyakshaya.
\end{abstract}

Key words: Aahara, Breast Milk, Prakriti, Stanya, Stanyakshaya, Vihara.

\section{INTRODUCTION}

Milk is the main and primary diet of Infant. Breast feeding was considered very excellent food for infants even in the Vedic Period. Rigveda has advocated breast feeding after birth with recitation of Mantras.

\section{Address for correspondence: \\ Dr. Kiran Tanwar \\ Post Graduate Scholar, Dept. of Sharira Kriya, \\ Ayurvedic and Unani Tibbia College, New Delhi, India. \\ E-mail: ankurkumartanwar@gmail.com}

Submission Date : 15/06/2016 Accepted Date: 24/06/2016

Website: www.jaims.in

Skanda mentioned in Dharama Granthas became popular as 'Kartikeya' only because of being breast fed by six 'Krttikas' ${ }^{[1]}$ this reference reflects the importance of breast milk. The breast milk provides numerous health benefits to both mother and baby. Breastfeeding should begin soon after birth. Breastfeeding is the best way to care for the new child. Besides the overwhelming bonding it creates, Breast milk is also the perfect food for them. The WHO recommends exclusive breastfeeding for the first six month of life, after which, infants should receive nutritionally adequate and safe complementary food while breastfeeding continues for upto two year of age or beyond. ${ }^{[2]}$

Stanyaksaya is a vital problem with increasing prevalence, ranging from $23-63 \%$ in western countries and $45-53 \%$ in some part of India. The overall scenario 
of this problem can be assessed by previous reports above cited. It is a great irony that such an important problem that is directly associated with the health of the mother and child is largely neglected. According to Sushruta, Stanyaksaya occurs due to psychological condition of mother (Krodha, Shoka, Bhaya, and Irsha \& Avatsalyatwa), Diet regime of mother and physiological condition. ${ }^{[3]}$

No specific effective and safe treatment has been proposed so far in conventional system of medicine. In Ayurveda on other hand possess a large number of the drugs, diet, and behavior regimen which are ascribed to be Stanyajanana and useful in the management of Stanyaksaya but scientific studies are not available to validate this. In the view of the above, present study was designed to evaluate the Stanyajanana effect of the Ahara and Vihara prescribed in the Ayurveda classics.

\section{Materials and Methods}

\section{Study design and Patient selection}

This was a single group clinical study conducted on 30 patients of Sthanya Kshaya attending the IPD and OPD of P.G. Department of Kriya Sharira of Ayurveda \& Unani Tibbia College, New Delhi, All patients were screened according to inclusion \& exclusion criteria and registered for the study.

\section{Inclusion and exclusion criteria}

Primi and multipara of above 18 years having Stanyaksaya and baby in Ksirapa Avastha were included in the study. Subjects below 18 years of age and suffering from Stanya Dushti, Diabeties mellitus, Hypothyroidism, hypopitutarism, inadequate breast tissue, retracted or flat nipples and diseases of breast and using certain medication such as bromocriptine, cabergolin, diuretics or antihistaminics etc. were excluded from the study, we also excluded the womens whose babies have cleft lip, cleft palate and babies suffered from acute and chronic debilitating illnesses, Babies on bottle feed were also excluded.

\section{Follow-up during study}

Mothers were managed on OPD basis and follow up was done fortnightly for 90 days. Follow up was done to note weight gain of baby or any problem and the clinical features of lactogenesis in mothers. Sustenance of the baby's growth was ensured.

\section{Criterion for assessment}

Subjective Parameters

1. Breast appearance: Stana Mlanata (laxity/ changing appearance), Shushkatwa (less in size/ wrinkled appearance)

2. Stanya Ejection: Stanya Alpata, Stanya Asambhav.

3. Breast feeding Frequency: Normal is 8-12 times. (Any reduced frequency of feeding was noted)

4. Pertaining to baby: hunger, cry, sleep, urine output and stool.

5. Residual milk in breast after each feeding.

\section{Objective Parameters}

Weight gain of the baby ( every 15 days interval)

\section{Assessment of Prakriti}

Assessment of Prakriti of every patient was done according to different parameters mentioned in Ayurvedic classics.

\section{Laboratory Investigations}

1. $\mathrm{Hb} \%$

2. $\mathrm{CBC}$

3. Urine routine / Micro

4. Serum Prolactin (if required only)

\section{Aahara Vihara for Participants}

The Aahara Vihara as mentioned in the classical literature was converted into a daily schedule chart, which was given to each of the participants selected for the management of Stanyakshaya.

Vihara

1. Avoidance of Hard work

2. Proper Rest

3. Happiness

4. Absence of Sorrow, Anger, fear

5. Avoidance of excessive walking 
Table 1: Diet chart for the Patients.

\begin{tabular}{|c|c|}
\hline $\begin{array}{l}\text { Early morning } \\
\text { (6:30 Am - 7:00 Am) }\end{array}$ & - Lemon Tea / Black Tea \\
\hline $\begin{array}{l}\text { Breakfast } \\
\text { (9:00 Am - 10:00 Am) }\end{array}$ & $\begin{array}{l}\text { - } \quad \text { Milk } 1 \text { glass } \\
\text { - } \quad \text { Sprouted grains (green gram) } \\
\text { - Pudding prepared by wheat } \\
\text { flour / Kheer prepared using } \\
\text { Jaggery / Laddoo prepared by } \\
\text { flours. }\end{array}$ \\
\hline $\begin{array}{l}\text { Lunch } \\
\text { (1:00 Pm - 2:00 Pm) }\end{array}$ & $\begin{array}{l}\text { - } 2 \text { Chapati (whole wheat) } \\
\text { - } \text { Rice } \\
\text { - } \quad \text { Dal } \\
\text { - } \quad \text { Green leafy vegetables / Meat } \\
\text { - } \quad \text { Curd } \\
\text { - } \quad \text { Onion and garlic Chutney. }\end{array}$ \\
\hline $\begin{array}{l}\text { Evening } \\
(4: 00 \mathrm{Pm}-5: 00 \mathrm{Pm})\end{array}$ & $\begin{array}{l}\text { - Milk } 1 \text { glass / Soup (tomato or } \\
\text { vegetable) / Meat soup / fruits }\end{array}$ \\
\hline $\begin{array}{l}\text { Dinner } \\
\text { (7.00 Pm - 8.00 Pm) }\end{array}$ & $\begin{array}{l}\text { - } 2 \text { Chapati (whole wheat) } \\
\text { - } \text { Rice } \\
\text { - } \text { Dal } \\
\text { - Green leafy vegetables / } \\
\text { Meat. }\end{array}$ \\
\hline Bed time (10.00 Pm) & $\begin{array}{l}\text { - Milk } 1 \text { glass (processed with } \\
\text { Shunti + Pippali) }\end{array}$ \\
\hline
\end{tabular}

\section{Observation AND Results}

Among the registered patients, highest no. of patients (56.60\%) belongs to the age group of $23-25$ followed by $(23.30 \%)$ in the age group of $26-28,(20 \%)$ of patients were observed in the age group of 20-22 and no patient was observed below 20yrs and above 28 years. Maximum number of patients (53.34\%) were Primipara followed by (46.66\%) Multipara. Maximum number of patients found in Higher secondary school category (43.30\%), in Graduation (26.60\%), and (16.60\%) were illiterate followed by (13.30\%) Primary school category. Majority of the patients (83.33\%) were House wife and (10\%) were working, followed by $(6.66 \%)$ who belongs to labour class category.
Maximum number (70\%) were in Urban areas and (30\%) were in Rural area. Maximum number (63.33\%) of Patients were taking vegetarian diet followed by (36.67\%) who were taking non vegetarian diet. Maximum no. of patients (46.7\%) had marital life of $3 \sim 4$ years followed by $(33.33 \%)$ having marital life of $1 \sim 2$ years and least no of patients (20\%) were having marital life of $5 \sim 6$ years. Maximun number (46.67\%) had Vata-Kapha Prakriti and (30\%) patients had VataPitta Prakriti and (23.33\%) and only (23.33\%) patients had Pitta -Kapha Prakriti. Highest number (40\%) patients had vishama Agni followed by (26.6\%) patients with Manda Agni and (20\%) patients with Sama Agni and only (13\%) patients had Teekshana Agni.

Table 2: Effect of therapy on breast milk ejection

\begin{tabular}{|c|c|c|c|c|}
\hline $\begin{array}{c}\text { Breast milk } \\
\text { ejection }\end{array}$ & $\begin{array}{c}\text { Mean } \pm S . D \\
\text { (B.T.) }\end{array}$ & $\begin{array}{c}\text { Mean } \pm S . D \\
\text { (A.T.) }\end{array}$ & $\begin{array}{c}\text { Change } \\
\text { in } \\
\text { Mean } \pm S . \\
\text { D } \\
\text { (B.T.- } \\
\text { A.T.) }\end{array}$ & $P$ value \\
\hline $\begin{array}{l}\text { Stanya } \\
\text { Alpata }\end{array}$ & $2.8 \pm 0.40$ & $2.4 \pm 0.56$ & 0.4 & 0.026 \\
\hline $\begin{array}{l}\text { Breast } \\
\text { feeding } \\
\text { frequency/ } \\
24 \mathrm{hrs}\end{array}$ & $5.63 \pm 0.8$ & $11.33 \pm 0.7$ & -5.7 & $<0.0001$ \\
\hline $\begin{array}{l}\text { Residual } \\
\text { milk in } \\
\text { breast after } \\
\text { each } \\
\text { feeding }\end{array}$ & $2.73 \pm 0.4$ & $2.36 \pm 0.5$ & 0.37 & 0.0068 \\
\hline
\end{tabular}

The mean and standard deviation of Stanya Alpata before and after 3 months of therapy is $2.8 \pm 0.40$ and $2.4 \pm 0.56$ with $p$ value is 0.026 which is considered statistically significant. The mean and standard deviation of Breast feeding frequency/24hrs before and after 3 months of therapy is $5.63 \pm 0.80$ and $11.33 \pm 0.71$ with $p$ value is $<0.0001$ which is considered statistically extremely significant. The mean and standard deviation of residual milk in breast after each feeding before and after 3 months of therapy is $2.73 \pm 0.44$ and $2.36 \pm 0.55$ with $p$ value is 
0.0068 which is considered statistically very significant. (Table 2)

Table 3: Effect of therapy on breast appearance

\begin{tabular}{|l|l|l|l|c|}
\hline \multicolumn{1}{|c|}{$\begin{array}{c}\text { Breast } \\
\text { Appearance }\end{array}$} & $\begin{array}{c}\text { Mean } \pm \text { S.D } \\
\text { (B.T.) }\end{array}$ & $\begin{array}{c}\text { Mean } \pm \text { S.D } \\
\text { (A.T.) }\end{array}$ & $\begin{array}{c}\text { Change in } \\
\text { Mean } \pm S . D \\
\text { (B.T.-A.T.) }\end{array}$ & $\begin{array}{c}\text { P } \\
\text { value }\end{array}$ \\
\hline $\begin{array}{l}\text { Stana } \\
\text { Mlanata }\end{array}$ & $2.7 \pm 0.466$ & $2.46 \pm 0.46$ & 0.24 & 0.006 \\
\hline $\begin{array}{l}\text { Stana } \\
\text { Shushkatwa }\end{array}$ & $2.68 \pm 0.54$ & $2.24 \pm 0.57$ & 0.24 & 0.003 \\
\hline
\end{tabular}

The mean and standard deviation of Stana Mlanata before and after 3 months of therapy is $2.7 \pm 0.466$ and $2.46 \pm 0.466$ with $p$ value is 0.0059 which is considered statistically significant. The mean and standard deviation of Stana Shushkatwa before and after 3months of therapy is $2.68 \pm 0.54$ and $2.24 \pm 0.57$ with $p$ value is 0.0035 which is considered statistically very significant. (Table 3 )

Table 4: Effect of therapy on clinical feature pertaining to baby

\begin{tabular}{|l|l|l|l|l|}
\hline \multicolumn{1}{|c|}{$\begin{array}{c}\text { Clinical } \\
\text { features }\end{array}$} & $\begin{array}{c}\text { Mean } \pm \text { S.D } \\
\text { (B.T.) }\end{array}$ & $\begin{array}{c}\text { Mean } \pm \text { S.D } \\
\text { (A.T.) } \\
\text { inge } \\
\text { Mean } \pm S \\
\text {.D } \\
\text { (B.T.- } \\
\text { A.T.) }\end{array}$ & P value \\
\hline $\begin{array}{l}\text { Hunger, } \\
\text { Cry, Sleep }\end{array}$ & $0.86 \pm 0.34$ & $0.5 \pm 0.508$ & 0.3 & 0.0018 \\
\hline $\begin{array}{l}\text { Frequency } \\
\text { of urine }\end{array}$ & $5.93 \pm 0.09$ & $9.8 \pm 0.96$ & 0.9 & $<0.0001$ \\
\hline $\begin{array}{l}\text { Frequency } \\
\text { of stool }\end{array}$ & $3.6 \pm 1.476$ & $7.53 \pm 1.90$ & 3.9 & $<0.0001$ \\
\hline
\end{tabular}

The mean and standard deviation of hunger, cry, sleep before and after 3 months of therapy is $0.866 \pm 0.345$ and $0.5 \pm 0.508$ with $p$ value is 0.0018 which is considered statistically very significant. The mean and standard deviation of frequency of urine before and after 3 months of therapy is $5.933 \pm 0.090$ and $9.8 \pm 0.96$ with $p$ value is $<0.0001$ which is considered statistically extremely significant. The mean and standard deviation of frequency of stool before and after 3 months of therapy is $3.6 \pm 1.476$ and $7.53 \pm 1.907$ with $\mathrm{p}$ value is $<0.0001$ which is considered statistically extremely significant.

\section{Discussion}

In Ayurvedic classics description of Stanya and its importance is mentioned in many places. Stanya is called by the synonym 'Piyusha'.

The Stanya is Jivana Amsha as it is the chief source of nutrition and diet to the infant due to Satmyatva. Considering this fact the intake of Stanya is advised from the day of birth which is to be continued until the age of two years. Thereby the growing infant requires adequate amounts of milk as it the only factor for causing Deha Pushti, Dhatu Vardhana and Bala Vardhana. According to Ayurveda, Breast milk is the essence of Rasadhatu which is formed from the digested food circulating in whole body, when it gets collected in breast it is termed as Stanya. As it is formed from Prasad Bhaga of Aahara Rasa it contains best of all nutrients needed for the child.

In Ayurveda causes for the Stanyanasha and Stanyaksaya are explained in detail by Sushruta, Kashyapa, Vagbhata $1 \& 2$ and Bhavaprakasha. Main causes are Langhana, Rukshannapana Sevana, Karshana, Atyanta Apatarpana, Shodhana Atiyoga, Krodha, Bhaya, Shoka, Kama and Avatsalyatwa, etc. psychosomatic causes. ${ }^{[20,21]}$ Hence Stanyaksaya occurs due to psychological condition and faulty diet regime of mother. Keeping these aspects in mind, this study has been undertaken and an attempt is made to see the efficacy of diet and behavioral regimen in improving the Stanyakshaya. A great deal of attention has been paid to the diet of the breast feeding mother all over the world. It isn't really surprising that many cultures make a direct connection between a woman's diet and the milk she produces for her child, so it is easy to understand why there are so many recommendations and taboos regarding what a breastfeeding mother eats. Some of these ideas do indeed have a basis, while others are the result of cultural attitudes, notions, and superstitions.

A healthy diet offers many advantages that go beyond those that directly affect the breastfeeding baby and mother. The ideal diet for a breastfeeding woman is simply the healthiest one for all human being. In our 
day to day lives, most of us have food habits that are not "ideal" but are still good enough to ensure that we have a sufficient quantity of the kinds of food. A woman who is not strict with her diet can still breastfeed successfully. A good nutrition help a mother maintain her health.

Ayurveda gives importance to breastfeeding from two view points-nutritional and psychological aspect. Nutritional value of breastfeeding has been recognized even by the modern medicine. There are certain dietary regulations prescribed by Ayurveda for breastfeeding.

\section{Conclusion}

This trial revealed that this disease is common in Vata-Kapha Prakriti patients. After treatment, statistically significant $(p<0.01)$ reduction was observed in selected parameters. We found that the Aahara-Vihara was found effective in Stanyaksaya. This may be due to Shlemsha Vardhaka. There was an increase in weight gain of infant, frequency of urine and stool output of infant. Breast appearences, breast milk ejection were improved after treatment. There was reduction in residual milk in breast after each feeding. However, no adverse effects were observed in trial group, as safety parameters were within normal limit during the study and overall compliance to the treatment were good. On the basis of above observation, it may be recommended that this diet (Aahara-Vihara) is a safe and effective in the management of Stanyaksaya.

\section{REFERENCES}

1. Aabhimanyu Kumar, Child Healthcare in Ayurveda, Sri Satguru Publications Delhi, 1999:17.

2. World Health Organization. (2003). Global strategy for infant and young child feeding. Geneva, Switzerland: World Health Organization and UNICEF. ISBN 92-4-156221-8. Retrieved 2009-09-20.

3. Maharshi Sushruta. Sushruta Samhita, Edited by Kaviraj Ambika Datt Shastri, Prastavana Lekhak - Dr Pranjivan M. Mehata, $12^{\text {th }}$ edition. Choukhamba Sanskrit Samsthan, Varanasi. 2001;1:106.

4. Chakrapanidatta. Chakradatta, with the 'Bhavathasandipini' Hindi commentary by Sri
Jagadishvaraprasad Tripathi. Chaukhambha Sanskrit series office, India. 5th Edition 1983:515

5. Maharshi Sushruta. Sushruta Samhita. Edited by Kaviraj Ambika Datt Shastri, Prastavana lekhak-Dr Pranjivan M. Mehata, $12^{\text {th }}$ edition. Choukhamba Sanskrit Samsthan, Varanasi. 2001;1:49

6. Maharshi Sushruta. Sushruta Samhita. Edited by Kaviraj Ambika Datt Shastri, Prastavana lekhak-Dr Pranjivan M. Mehata, $12^{\text {th }}$ edition. Choukhamba Sanskrit Samsthan, Varanasi. 2001;172

7. Charaka 'Charaka Samhita' of Agnivesh elaborated by Charaka \& redacted by Dradhabala Volume 1 Edited with 'Vaidyamanorama' Hindi commentary along with special deliberation etc by Acharya Shukla \& Prof Ravi Dutt Tripathi forwad by Acharya Priyvrata Sharma, Publication- Choukhambha Sanskrit Samsthan Delhi. 2014:144.

8. Bhela - Bhela-Samhita. Text with English Translation, commentary, and critical notes by Dr. K.H. Krishna Murthy- Chaukhambha Vishvabharati. Reprint edition. Oriental Publishers and Distributors. Varanasi. 2003:146.

9. Maharshi Sushruta 'Sushruta Samhita' Pratham bhag, Edited by Kaviraj Ambika Datt Shastri, Prastavana lekhak-Dr Pranjivan M. Mehata, PublicationChoukhamba Sanskrit Samsthan,Varanasi $12^{\text {th }}$ edition 2001;49

10. Charaka 'Charaka Samhita' of Agnivesh elaborated by Charaka \& redacted by Dradhabala Volume 1 Edited with 'Vaidyamanorama' Hindi commentary along with special deliberation etc by Acharya Shukla \& Prof Ravi Dutt Tripathi forwad by Acharya Priyvrata Sharma, Publication- Choukhambha Sanskrit Samsthan Delhi, 2014:906

11. Sharangadhara. Sharangadhara Samhita- A treatise on Ayurveda. Translated into English by K.R. Srikanta, Murthy. Chaukhambha Orientalia, Varanasi. 2003:53

12. Maharshi Sushruta 'Sushruta Samhita' Pratham bhag, Edited by Kaviraj Ambika Datt Shastri, Prastavana lekhak-Dr Pranjivan M. Mehata, PublicationChoukhamba Sanskrit Samsthan,Varanasi $12^{\text {th }}$ edition $2001 ; 270$

13. Vagbhata. Acharya. Astanga. Samgraha. (Text, English translation, Notes, Appendex, Indices) Translated by 


\section{ORIGINAL ARTICLE May-June 2016}

Prof. K.R.Srikantha. Murthy. Chaukhambha Orientalia, Varanasi. 9th Edition 2005;3

14. Charaka 'Charaka Samhita' of Agnivesh elaborated by Charaka \& redacted by Dradhabala Volume 1 Edited with 'Vaidyamanorama' Hindi commentary along with special deliberation etc by Acharya Vidhyadhar Shukla \& Prof Ravi Dutt Tripathi forwad by Acharya Priyvrata Sharma, Publication- Choukhambha Sanskrit Samsthan Delhi, 2014:959

15. Maharshi Sushruta 'Sushruta Samhita' Pratham bhag, Edited by Kaviraj Ambika Datt Shastri, Prastavana lekhak-Dr Pranjivan M. Mehata, PublicationChoukhamba Sanskrit Samsthan,Varanasi $12^{\text {th }}$ edition $2001 ; 79$

16. Sushruta. Sushruta Samhita with Nibandha Sangraha comm.. of Dalhanacarya and Nyayacandrika Panjika comm.. of Gayadasacarya on Nindana Sthana (Shariraa 10/13)

17. An investigation of the problems experienced with breastfeeding and the reason for early breastfeeding failure among primiparous woman. Breastfeeding review 1988;12;73-74

18. Srivastava DK, Sahni OP, Kumar A. Infant feeding with commercial milk formula;185

19. Maharshi Sushruta. Sushruta Samhita. Edited by Kaviraj Ambika Datt Shastri, Prastavana lekhak-Dr Pranjivan M. Mehata, 12th edition. Choukhamba Sanskrit Samsthan,Varanasi. 2001:1;79

20. Sjolins, Hofvonder Y, Hillervik C. Factors related to Early termination of Breastfeeding. Acta Pediatr Scand 1977:66:505-11..

How to cite this article: Kiran Tanwar, Uma Shankar Sharma, Ankur Kumar Tanwar. To Evaluate the efficacy of Aahara -Vihara on Stanya Kshaya in Healthy Female Volunteers of different Deha Prakriti. J Ayurveda Integr Med Sci 2016;1(1):1-6. http://dx.doi.org/10.21760/jaims.v1i1.3628

Source of Support: Nil, Conflict of Interest: None declared. 